\title{
Tissue-Specific Gene Expression
}

National Cancer Institute

\section{Source}

National Cancer Institute. Tissue-Specific Gene Expression. NCI Thesaurus. Code C19563.

Expression of different genes in different tissues. 